\title{
Fresh pasta enrichment with protein concentrate of tilapia: nutritional and sensory characteristics
}

\author{
Elenice Souza dos Reis GOES ${ }^{1 *}$, Maria Luiza Rodrigues de SOUZA², Jane Martha Graton MICHKA ${ }^{3}$, \\ Katia Setsuko KIMURA², Jorge Antônio Ferreira de LARA ${ }^{4}$, Adina Cléia Botazzo DELBEM ${ }^{4}$, Eliane GASPARINO ${ }^{2}$
}

\begin{abstract}
With the goal of developing and characterizing the nutritional and sensory aspects of fresh pasta supplemented with tilapia protein concentrate, four types of pasta were prepared, with inclusion of $0,10,20$, or $30 \%$ of tilapia protein concentrate. Linear effects were observed $(\mathrm{P}<0.01)$ in crude protein, total lipids, ash, carbohydrate, and caloric values; these parameters increased with increasing amounts of tilapia protein concentrate in the pasta. The concentration of $\mathrm{Na}, \mathrm{P}, \mathrm{Ca}, \mathrm{Mg}$, and $\mathrm{Zn}$ increased linearly $(\mathrm{P}<0.01)$ in correlation with the increase in protein concentrate content, while Fe content decreased linearly $(\mathrm{P}<0.01)$. In the sensory analysis, texture, overall impression, and the acceptance index demonstrated a cubic regression $(\mathrm{P}<0.05)$, with the inclusion of $20 \%$ protein concentrate yielding the best scores. Including up to $30 \%$ of tilapia protein concentrate in pasta yields an increased nutritional value, but based on the sensory results, $20 \%$ of tilapia protein concentrate in pasta is the recommended maximum level.
\end{abstract}

Keywords: filleting residue; fish protein concentrate; fish technology; Oreochromis niloticus.

Practical Application: Mass can be nutritionally enriched with fish.

\section{Introduction}

Fish have a high nutritional value because they provide high quality protein, are rich in essential amino acids, are a good source of complex B vitamins, and contain a wide variety of minerals including phosphorus, magnesium, iron, zinc, and even iodine in marine fish (Ariño et al., 2013).

The Nile tilapia (Oreochromis niloticus) stands out in the aquaculture industry as one of the most cultivated freshwater fish in the world (Chen et al., 2013); this fact is due to several technologic enhancements and the intensification of cultivation practices (Fuchs et al., 2013), which contributed to the quality of white meat and the removal of fish bones during the filleting process. Studies regarding the utilization of the residues generated by the filleting process of this species have the potential to add value and to increase Brazilian aquaculture production, because tilapia is the most highly produced species in Brazil (Instituto Brasileiro de Geografia e Estatística, 2014).

Thus, fish protein concentrate has been highly studied due to its nutritional characteristics and its potential for human consumption, as shown by Godoy et al. (2013), who developed the flavored fish meal using Nile tilapia carcasses. Flour made from the heads and bones of tilapia (O. mossambicus) was prepared by Vignesh \& Srinivasan (2012) and they observed that the flour contained seven essential minerals (calcium, iron, potassium, magnesium, copper, sodium, and zinc). Other studies have been performed to improve the nutritional value of several food products (broth and soup, extruded snacks, cookies, and crackers) by including fish meal (Godoy et al., 2010; Justen et al., 2011; Franco et al., 2013). This inclusion is a good way to increase fish intake in the country once people are buying more industrialized and fast food products, easy to prepare and nutritious, but low-calorie.

Noodles are a popular product due to their low cost, ease of transportation, long shelf life, and their nutritional properties, as pasta provides significant amounts of carbohydrates, protein, and complex B vitamins (Fradique et al., 2013). Some works have already been developed for inclusion in fish noodles, such as Reis (2013) that prepared a dry pasta with $10 \%$ of tilapia protein concentrate that was mechanically separated, thereby obtaining a product with a greater protein content and good sensory qualities. Also fresh pasta that included $30.6 \%$ of cured pacu fillets (Piaractus mesopotamicus) was developed by Maluf et al. (2010), and they obtained noodles with $15.2 \%$ crude protein.

Therefore, the aim of this study was to develop a fresh pasta enriched with protein concentrate made from Nile tilapia filleting residue, and to evaluate the obtained pasta in terms of chemical composition, mineral content, and to conduct sensory and microbiologic analyses. 


\section{Materials and methods}

The protein concentrate made from Nile tilapia was produced at the Fish Technology Laboratory at the Iguatemi Experimental Farm of the Universidade Estadual de Maringá (UEM). Frozen Nile tilapia carcasses (spines with ribs and remaining meat filleting) without fins, which were byproducts of the filleting process at the Smartfish Company located in Rolândia, Paraná, Brazil, were washed in a chloride water solution and baked for 60 minutes using an industrial pressure cooker. Afterwards, the material was pressed in a hydraulic press (10 tons) and the pressed material was ground using an electric meat mill. The resulting mass was dehydrated in a forced air oven at $60{ }^{\circ} \mathrm{C}$ for 24 hours, and the fish protein concentrate obtained from this process was used in the manufacturing of the noodles.

Wheat flour, protein concentrate from Nile tilapia, eggs, common salt, and water were used to prepare the pasta; the fish protein concentrate was included in the following levels: $0,10,20$, and $30 \%$, partially replacing the total wheat flour according to the values shown in Table 1 . The dried ingredients were weighed, screened, and mixed. After the addition of eggs and water, the dough was manually kneaded. Then, the dough was molded into thin noodles, sectioned, and stored under refrigeration $\left(5 \pm 2{ }^{\circ} \mathrm{C}\right)$ until the analyses.

Microbiologic analyses were performed on the protein concentrate and pasta in each treatment. Microbiologic analyses of the samples were performed to determine the most probable number (MPN) of coliforms at $35^{\circ}$ and $45^{\circ}$, positive coagulase count of Staphylococcus in CFU/g, and the presence of Salmonella sp (American Public Health Association, 2001).

Chemical composition and mineral content analyses were conducted. The determination of moisture, crude protein, total lipids, and ash content were performed in triplicate according to the AOAC (Associations of Official Analytical Chemists, 2005) methodology. Carbohydrate content was determined by calculating the difference between the other components (Brasil, 2003). Total caloric value was obtained by the sum of the multiplication of protein, lipids, and carbohydrates means multiplied by the factors 4, 9, and 4 respectively (Souci et al., 2000).

Mineral contents were analyzed in the pasta to evaluate sodium $(\mathrm{Na})$, potassium $(\mathrm{K})$, phosphorus $(\mathrm{P})$, calcium $(\mathrm{Ca})$, magnesium $(\mathrm{Mg})$, iron $(\mathrm{Fe})$, manganese $(\mathrm{Mn})$, zinc $(\mathrm{Zn})$, and copper $(\mathrm{Cu})$. Phosphorus was determined by using ammonium phosphomolybdate and UV-VIS spectrophotometry according to Eijsink et al. (1997). For the determination of calcium and

Table 1. Formulation of fresh pasta dough with the inclusion of different levels of tilapia protein concentrate.

\begin{tabular}{lcccc}
\hline \multirow{2}{*}{\multicolumn{1}{c}{ Ingredients }} & \multicolumn{4}{c}{ Tilapia protein concentrate } \\
inclusion \\
\cline { 2 - 5 } & $\mathbf{0 \%}$ & $\mathbf{1 0 \%}$ & $\mathbf{2 0 \%}$ & $\mathbf{3 0 \%}$ \\
\hline Wheat flour $(\mathrm{g})$ & 580 & 522 & 464 & 406 \\
Tilapia protein concentrate $(\mathrm{g})$ & 0 & 58 & 116 & 174 \\
Egg $(\mathrm{g})$ & 62.5 & 62.5 & 62.5 & 62.5 \\
Water $(\mathrm{mL})$ & 250 & 250 & 250 & 250 \\
Common salt $(\mathrm{g})$ & 7.5 & 7.5 & 7.5 & 7.5 \\
\hline
\end{tabular}

iron, the samples were digested in acid and the quantification was performed using flame atomic absorption spectrophotometry (Zhou et al., 1998). For the determination of the other minerals, atomic absorption spectrophotometry (model Perkin Elmer 3300) was utilized and calibrated for a specific wave length, split, and mixture of the gases for each element. To create the calibration curves, standard ampoules were used for Merck atomic absorption and appropriately diluted with deionized water. Analyses were performed in triplicate.

For the sensory analyses, the noodle samples were cooked with water and salt for 20 minutes, and after tomato sauce was added. The sensory analysis was conducted with 40 non-trained academic tasters from UEM. Methods of sensory analysis was approved by the Comitê Permanente de Ética em Pesquisa com Seres Humanos (COPEP) of the Universidade Estadual de Maringá, Maringá PR Brazil (Protocol 458.151/2013-COPEP). The samples (around $25 \mathrm{~g}$ ) were offered to the tasters on a disposable plastic plate, and each sample was identified by three random numbers. A water bottle was offered with the samples to remove any residual flavor from the mouth. Appearance, aroma, flavor, texture, and overall impression were evaluated using a 9-point hedonic scale with a minimum of 1 (extremely disliked) and a maximum of 9 (extremely liked) (Dutcosky, 2007). To evaluate the Acceptance Index (AI) for the products, the Expression 1 was used (Dutcosky, 2007).

$A I \%=\frac{\text { average grade obtained for product }}{9} \times 100$

In addition, the intention to purchase the products was evaluated using a 5-point hedonic scale with a minimum of 1 (would definitely not buy) and maximum of 5 (definitely would buy) (Damásio \& Silva, 1996).

Data obtained for the different analyses were submitted to a linear regression analysis with a 5\% significance using the statistical program Statistical Analysis System (SAS, SAS Inst. Inc. Cary, NC, USA).

\section{Results and discussion}

According to the National Health Surveillance Agency ANVISA (Brasil, 2001), the law establishes that frozen or cooled fish and fish based products cannot have a Staphylococcus count greater than $10^{3}$. A $<1 \times 10^{2}$ positive coagulase Staphylococcus count was verified for the tilapia protein concentrate and the formulation used in the noodles. The law also establishes that fecal coliforms have a limit of $10^{2} \mathrm{MPN} / \mathrm{g}$ for pre-cooked or breaded food; the values observed in this study were lower than those established by the law for all treatments. Salmonella spp were absent in $25 \mathrm{~g}$ of the analyzed sample (Table 2).

In relation to the chemical composition (Table 3 ), positives linear effects $(\mathrm{P}<0.01)$ were observed for crude protein $(\mathrm{y}=28.422 \mathrm{x}$ $\left.+9.704, \mathrm{R}^{2}=0.98\right)$, total lipids $\left(\mathrm{y}=1.132 \mathrm{x}+1.084, \mathrm{R}^{2}=0.60\right)$, ash $\left(y=17.732 x+1.115, R^{2}=0.95\right)$, and negatives linear effects for carbohydrates $\left(\mathrm{y}=-46.061 \mathrm{x}+50.592, \mathrm{R}^{2}=0.96\right)$, and caloric value $\left(y=-60.367 x+250.940, R^{2}=0.77\right)$ contents. This helped to verify that with an increase in the levels of tilapia protein concentrate, the crude protein, total lipids, and ash contents 
Table 2. Microbiologic analysis of tilapia protein concentrate and of fresh pasta containing tilapia protein concentrate.

\begin{tabular}{|c|c|c|c|c|c|}
\hline & \multirow{2}{*}{$\begin{array}{l}\text { Tilapia protein } \\
\text { concentrate }\end{array}$} & \multicolumn{4}{|c|}{ Inclusion levels of tilapia protein concentrate } \\
\hline & & $\mathbf{0 \%}$ & $10 \%$ & $20 \%$ & $30 \%$ \\
\hline Coliforms at $35^{\circ} \mathrm{C}(\mathrm{MPN} / \mathrm{g})$ & $<3$ & $<3$ & $<3$ & $<3$ & $<3$ \\
\hline Salmonella sp & Absent in $25 \mathrm{~g}$ & Absent in $25 \mathrm{~g}$ & Absent in $25 \mathrm{~g}$ & Absent in $25 \mathrm{~g}$ & Absent in $25 \mathrm{~g}$ \\
\hline Coagulase positive Staphylococcus (CFU/g) & $<1 \times 10^{2}$ & $<1 \times 10^{2}$ & $<1 \times 10^{2}$ & $<1 \times 10^{2}$ & $<1 \times 10^{2}$ \\
\hline
\end{tabular}

Table 3. Chemical composition of fresh pasta containing tilapia protein concentrate.

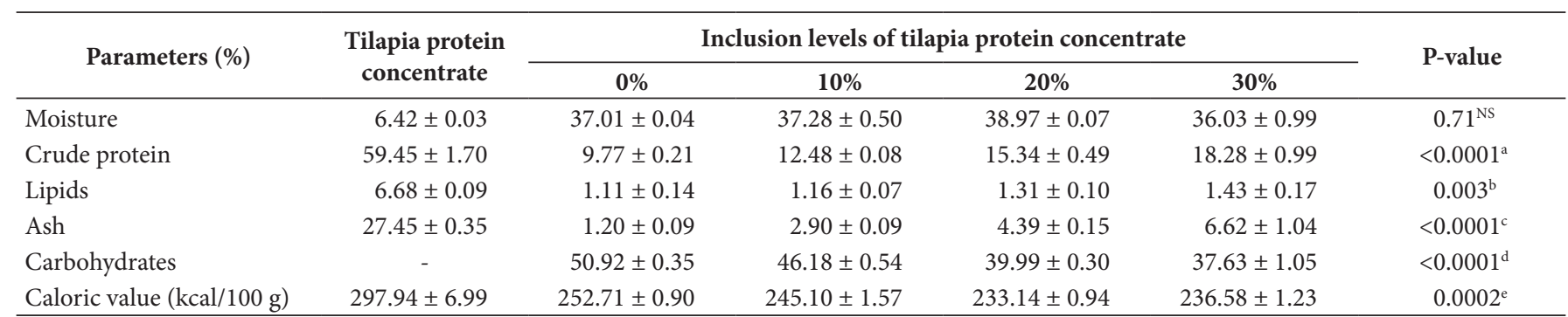

Values expressed as the mean \pm standard deviation. NS $=$ Non-significant. ${ }^{2}$ Linear effect: $y=28.422 x+9.7043 . R^{2}=0.98$. ${ }^{b}$ Linear effect: $y=1.132 x+1.084 . R^{2}=0.60$. ${ }^{c}$ Linear effect: $\mathrm{y}=17.732 \mathrm{x}+1.115 \mathrm{R}^{2}=0.95 .{ }^{\mathrm{d}}$ Linear effect: $\mathrm{y}=-46.061 \mathrm{x}+50.592 \mathrm{R}^{2}=0.96 .{ }^{e}$ Linear effect: $\mathrm{y}=-60.367 \mathrm{x}+250.940 \mathrm{R}^{2}=0.77$.

increased linearly, whereas the carbohydrate content and caloric value decreased. This observation is related to the composition of the tilapia protein concentrate utilized in this experiment (Table 3). Tilapia protein concentrate contained $59.5 \%$ crude protein, $6.68 \%$ total lipids, and $27.5 \%$ ash. Thus, the inclusion of this ingredient in the pasta was responsible for the linear increase in the noodles' nutritional values.

Moisture content did not differ $(\mathrm{P}>0.05)$ among pastas in this study, where values ranged between 36.03 to $38.97 \%$. According to Reis (2013), drying pasta is an alternative method to decrease moisture content and to concentrate the nutrients.

Dried pasta normally contains an average protein content of $11.5 \%$ (Belitz et al., 2009). The inclusion of $30.6 \%$ of cured pacu meat (Piaractus mesopotamicus) in fresh pasta yielded $15.21 \%$ of crude protein and $9.73 \%$ of total lipids in noodles (Maluf et al., 2010). Thus, the inclusion of mechanically separated tilapia protein concentrate in dry pasta increased the crude protein content from $13.28 \%$ at the level of $0 \%$ protein concentrate, to $17.80 \%$ at the level of $10 \%$ protein concentrate Reis (2013); this supports the results obtained in the present study. The maximum level of tilapia protein concentrate that was included (30\%) in fresh pasta in this study resulted in a product with $18.28 \%$ of crude protein. It is worth noting that the protein quality of the noodles with protein concentrate is greater than others, because fish and their derivatives contain a high biologic protein with a balanced amino acid profile and a good proportion of methionine and cysteine, which are the main limiting amino acids in vegetal protein sources (Neves et al., 2004). Previous studies evaluating the amino acid composition in tilapia protein concentrate (Souza et al., 2016) showed that protein concentrate also contains all essential amino acids, and that the amino acid content is much greater than the standard required by the FAO
(Food and Agriculture Organization of the United Nations) for both children and adults (World Health Organization, 2007).

When Costa et al. (1990) evaluated the inclusion of concentrated Trahira protein (Hoplias malabaricus) in noodles, where Trahira protein replaced $5,10,15$, or $20 \%$ of the wheat flour, they obtained a concentrate with $84.3 \%$ of crude protein. These authors also observed that the addition of protein concentrate in noodles led to a darkening that was proportionate to the level of added protein. The same phenomenon was observed in this study; once the protein concentrate was added to the pasta, the degree of darkening increased in the fresh pasta before baking. The dough was stretched by using a cylinder, as the texture resulted in a less malleable pasta that was more easily manipulated by using a manual cylinder.

Total lipids content in the noodles in this study increased linearly from 1.11 to $1.43 \%$, based on the different amounts of tilapia protein concentrate included in the pasta. Total lipids in tilapia yielded a good fatty acid profile, as Petenuci et al. (2010) observed in flour made from tilapia backbones. These authors identified 24 fatty acids in flour with primarily the following fatty acids: $27.4 \%$ of palmitic acid (C16:0), 35.15\% of oleic acid (C18:1n-9), 11.82\% of linoleic acid (C18:2n-6), and in a lower proportion: $0.88 \%$ of alpha-linolenic acid (C18:3n-3), $0.08 \%$ of eicosapentanoic acid (C20:5n-3), and $0.59 \%$ of docosahexaenoic acid (C22:6n-3) (Petenuci et al., 2010). No presented data regarding tilapia protein concentrate used to prepare noodles in this study presented $21.16 \%$ of polyunsaturated fatty acids (PUFA) in tilapia protein concentrate which $4.28 \%$ are omega-3 and $12.26 \%$ are omega- 6 (Souza et al., 2016).

Pasta is a product that contains large amounts of complex carbohydrates (Giese, 1992), while dry pasta contains an average of $70 \mathrm{~g}$ of carbohydrates/100 $\mathrm{g}$ of pasta and an abundant amount 
of starch (63 g/100 g) (Belitz et al., 2009). In the present study, the carbohydrate content in the fresh pasta decreased linearly from $50.92 \%$ ( $0 \%$ tilapia protein concentrate included) to $37.63 \%$ ( $30 \%$ of tilapia protein concentrate included); this result may be explained by the linear increase in the other pasta components (crude protein, total lipids, and ash). Pasta is also a high energy food (Nicoletti et al., 2007), which was observed in this study, as the fresh pasta without tilapia protein concentrate yielded a caloric value of $252.71 \mathrm{kcal} / 100 \mathrm{~g}$. The inclusion of protein concentrate led to a linear decrease in this parameter, where the maximum inclusion level (30\%) yielded a caloric value of $236.58 \mathrm{kcal} / 100 \mathrm{~g}$. This lower caloric value was due to the reduction in carbohydrates and the increase in crude protein content, which resulted in a better nutritional value for pasta that included tilapia protein concentrate. With the goal of decreasing the energy value of noodles, Nicoletti et al. (2007) prepared a dry pasta using soybean meal and broken rice, thus obtaining a product with $393.47 \mathrm{kcal}$ and $21.11 \%$ crude protein.

In the present study, ash content (Table 3) demonstrated a linear increase associated with the addition of tilapia protein concentrate, which can be associated with the ash content in the tilapia protein concentrate (27.45\%). The fabrication process of tilapia protein concentrate aggregates nutrients and minerals found naturally in fish; therefore, the greater ash levels observed in noodles with tilapia protein concentrate is important because the noodles can be a source of several essential minerals. According to Sartori \& Amancio (2012), the fish meat is a main source of calcium and phosphorus, but also contains iron, copper, and selenium. The mineral composition for developed noodles in the current study supports these claims, which can be observed in Table 4.

Sodium, phosphorus, calcium, magnesium, and zinc contents increased linearly $(\mathrm{P}<0.01)$ according to the increasing levels of protein concentrate based on the following equations: $y=3.753 \times+2.700\left(R^{2}=0.77\right)$ for sodium, $y=24.220 x+0.982$ $\left(\mathrm{R}^{2}=0.99\right)$ for phosphorus, $\mathrm{y}=44.573 \times-0.349\left(\mathrm{R}^{2}=0.98\right)$ for calcium, $y=0.580 x+0.153\left(R^{2}=0.77\right)$ for magnesium, and $y=10.397 x+9.328\left(R^{2}=0.84\right)$ for zinc. However, iron concentrations decreased linearly $(\mathrm{P}<0.01)$ with increasing levels of protein concentrate $\left(y=-89.357 x+80.159, R^{2}=0.87\right)$. Potassium, manganese, and copper contents in the pasta were not significantly affected $(\mathrm{P}>0.05)$ by the inclusion of tilapia protein concentrate.

Five macro minerals (sodium, potassium, magnesium, calcium, and phosphorus) and four trace minerals (iron, manganese, copper, and zinc) are needed for the regulation of healthy functions in the human body. In addition, calcium, phosphorus, and magnesium are involved in bone health (Hosseini et al., 2014). The fish meat is a valuable source of calcium and phosphorus (Simões et al., 2007). This statement was observed in the present study, as these mineral contents increased linearly when the tilapia protein concentrate was included. This fact was also observed by Reis (2013); when they prepared dry pasta with the inclusion of 0.0 , $2.5,5.0,7.5$, and $10 \%$ of mechanically separated tilapia protein concentrate, they obtained the most calcium $(0.066 \mathrm{mg} / \mathrm{kg})$ and phosphorus $(0.256 \mathrm{mg} / \mathrm{kg})$ levels in noodles when they added $10 \%$ of mechanically separated tilapia protein concentrate.

Iron is the most abundant trace mineral in the human body, and an insufficient daily consumption may result in anemia (Hosseini et al., 2014). In the present study, iron concentration decreased linearly from $78.71 \mathrm{mg} / \mathrm{kg}$ ( $0 \%$ tilapia protein concentrate inclusion) to $51.33 \mathrm{mg} / \mathrm{kg}$ (30\% tilapia protein concentrate included). This occurred because the inclusion of tilapia protein concentrate was achieved by reducing wheat flour content, and because the wheat flour used to produce the pasta was enriched with iron and folic acid. In Brazil, a specific law (Resolution RDC no 344, December 13th 2002) determined that from 2004, each $100 \mathrm{~g}$ of wheat flour should contain $4.2 \mathrm{mg}$ of iron and $150 \mathrm{mcg}$ of folic acid (Brasil, 2002). The lowest iron content observed in the present study $(51.33 \mathrm{mg} / \mathrm{kg})$ is much greater than the Recommended Daily Intake (RDI) of iron, which is $14 \mathrm{mg}$ for adults (Food and Agriculture Organization of the United Nations, 2001).

Sodium regulates the osmotic pressure of tissues in the human body, although excessive consumption may lead to hypertension (Karppanen \& Mervaala, 2006). The World Health Organization's (WHO) recommendation for the maximum daily intake of sodium in adults is $2000 \mathrm{mg}$ (equal to $5 \mathrm{~g}$ of common salt) (Nilson et al., 2012). In pasta with tilapia protein concentrate included, sodium content increased linearly with the increase in tilapia protein concentrate, with values ranging from

Table 4. Mineral composition of fresh pasta with the inclusion of tilapia protein concentrate.

\begin{tabular}{|c|c|c|c|c|c|c|}
\hline \multirow{2}{*}{ Minerals } & \multirow{2}{*}{$\begin{array}{l}\text { Tilapia protein } \\
\text { concentrate }\end{array}$} & \multicolumn{5}{|c|}{ Inclusion levels of tilapia protein concentrate } \\
\hline & & $\mathbf{0 \%}$ & $10 \%$ & $20 \%$ & $30 \%$ & P-value \\
\hline Calcium $(\mathrm{g} / \mathrm{kg})$ & $7.09 \pm 0.92$ & $0.14 \pm 0.02$ & $3.18 \pm 0.17$ & $8.94 \pm 1.01$ & $13.08 \pm 0.37$ & $<0.0001^{\mathrm{a}}$ \\
\hline Copper $(\mathrm{mg} / \mathrm{kg})$ & $0.78 \pm 0.37$ & $2.71 \pm 0.53$ & $2.47 \pm 0.53$ & $2.91 \pm 1.36$ & $1.77 \pm 0.14$ & $0.2709^{\mathrm{Ns}}$ \\
\hline Iron $(\mathrm{mg} / \mathrm{kg})$ & $146.12 \pm 25.55$ & $78.71 \pm 4.03$ & $72.10 \pm 2.39$ & $64.88 \pm 6.61$ & $51.33 \pm 1.13$ & $<0.0001^{\mathrm{b}}$ \\
\hline Phosphorus (g/kg) & $5.13 \pm 0.66$ & $1.22 \pm 0.11$ & $2.98 \pm 0.11$ & $5.97 \pm 0.08$ & $8.29 \pm 0.14$ & $<0.0001^{\mathrm{c}}$ \\
\hline Magnesium (g/kg) & $2.26 \pm 0.06$ & $0.17 \pm 0.02$ & $0.17 \pm 0.04$ & $0.30 \pm 0.02$ & $0.32 \pm 0.03$ & $0.0002^{\mathrm{d}}$ \\
\hline Manganese (mg/kg) & $2.20 \pm 0.92$ & $5.92 \pm 0.14$ & $6.12 \pm 0.32$ & $5.78 \pm 0.29$ & $6.09 \pm 0.41$ & $0.8238^{\mathrm{NS}}$ \\
\hline Potassium $(\mathrm{g} / \mathrm{kg})$ & $1.39 \pm 0.06$ & $1.20 \pm 0.16$ & $1.21 \pm 0.27$ & $1.22 \pm 0.27$ & $1.56 \pm 0.49$ & $0.1855^{\mathrm{NS}}$ \\
\hline Sodium $(\mathrm{g} / \mathrm{kg})$ & $6.43 \pm 0.11$ & $2.78 \pm 0.09$ & $2.93 \pm 0.38$ & $3.51 \pm 0.35$ & $3.84 \pm 0.02$ & $0.0002^{\mathrm{e}}$ \\
\hline Zinc (mg/kg) & $3.93 \pm 1.07$ & $9.00 \pm 0.33$ & $10.62 \pm 0.21$ & $11.88 \pm 0.61$ & $12.05 \pm 0.42$ & $<0.0001^{\mathrm{f}}$ \\
\hline
\end{tabular}

Values expressed as mean \pm standard deviation. $N S=$ Non-significant. ${ }^{a}$ Linear effect: $\mathrm{y}=44.573 \mathrm{x}-0.349 \mathrm{R}^{2}=0.98 .{ }^{\mathrm{b}}$ Linear effect: $\mathrm{y}=-89.357 \mathrm{x}+80.159 \mathrm{R}^{2}=0.87 .{ }^{\mathrm{c}}$ Linear effect: $\mathrm{y}=24.220 \mathrm{x}$ $+0.982 \mathrm{R}^{2}=0.99 .{ }^{\mathrm{d}}$ Linear effect: $\mathrm{y}=0.580 \mathrm{x}+0.153 \mathrm{R}^{2}=0.77 .{ }^{\mathrm{e}}$ Linear effect: $\mathrm{y}=3.753 \mathrm{x}+2.700 . \mathrm{R}^{2}=0.77 .{ }^{\mathrm{f}}$ Linear effect: $\mathrm{y}=10.397 \mathrm{x}+9.328 \mathrm{R}^{2}=0.84$ 
Fresh pasta enrichment with fish protein

Table 5. Characteristics profile and intent to purchase of fresh pasta with tilapia protein concentrate.

\begin{tabular}{lccccc}
\hline \multirow{2}{*}{\multicolumn{1}{c}{ Attributes }} & \multicolumn{3}{c}{ Inclusion levels of tilapia protein concentrate } & \multicolumn{2}{c}{ P-value } \\
\cline { 2 - 5 } & $\mathbf{0 \%}$ & $\mathbf{1 0 \%}$ & $\mathbf{2 0 \%}$ & $\mathbf{3 0 \%}$ & $0.25^{\mathrm{NS}}$ \\
Color $^{1}$ & $6.88 \pm 1.77$ & $6.73 \pm 1.43$ & $7.00 \pm 1.28$ & $6.35 \pm 1.81$ & $0.51^{\mathrm{NS}}$ \\
Aroma $^{1}$ & $6.75 \pm 1.85$ & $6.68 \pm 1.40$ & $6.90 \pm 1.57$ & $6.43 \pm 1.52$ & $<0.05^{\mathrm{a}}$ \\
Texture $^{1}$ & $7.05 \pm 1.87$ & $6.55 \pm 1.66$ & $7.95 \pm 6.32$ & $5.98 \pm 2.08$ & $<.08$ \\
Flavor $^{1}$ & $6.48 \pm 2.11$ & $5.98 \pm 2.03$ & $6.40 \pm 2.07$ & $5.60 \pm 2.17$ & $<0.05^{\mathrm{c}}$ \\
Overall impression $^{1}$ & $6.85 \pm 1.89$ & $6.03 \pm 1.99$ & $6.68 \pm 1.83$ & $65.67 \pm 18.00$ & $<0.05^{\mathrm{d}}$ \\
Acceptance index (\%) $^{\mathrm{d}}$ & $75.56 \pm 18.10$ & $71.00 \pm 16.19$ & $77.61 \pm 17.22$ & $2.78 \pm 1.40$ & $0.02^{\mathrm{e}}$ \\
Purchase intention $^{2}$ & $3.53 \pm 1.28$ & $3.45 \pm 1.18$ & $3.50 \pm 1.20$ & & \\
\hline
\end{tabular}

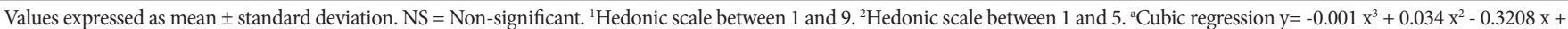
$7.050 \mathrm{R}^{2}=0.99$. ${ }^{\mathrm{b}}$ Linear regression $\mathrm{y}=6.523-0.034 \mathrm{x} \mathrm{R}^{2}=0.56 .{ }^{\mathrm{c} C u b i c}$ regression $\mathrm{y}=-0.0005 \mathrm{x}^{3}+0.023 \mathrm{x}^{2}-0.263 \mathrm{x}+6.850 \mathrm{R}^{2}=0.99 .{ }^{\mathrm{d}} \mathrm{Cubic}$ regression $\mathrm{y}=-0.005 \mathrm{x}^{3}+0.204 \mathrm{x}^{2}-2.005 \mathrm{x}+75.556$ $\mathrm{R}^{2}=0.99$. ${ }^{\mathrm{e}}$ Linear effect $\mathrm{y}=3.643-0.022 \mathrm{x}, \mathrm{R}^{2}=0.62$.

2.78 to $3.84 \mathrm{~g} / \mathrm{kg}$. However, Reis (2013) did not observe changes in sodium content in dry pasta with 0 to $10 \%$ mechanically separated tilapia protein concentrate, with values ranging from 394.266 to $397.600 \mathrm{mg} / \mathrm{kg}$ sodium.

Magnesium, manganese, and zinc are responsible for regulating the activity of several enzymes (Taskaya et al., 2009). In the present study, we observed that magnesium and zinc displayed a linear increase with increasing levels of tilapia protein concentrate included in noodles. When studying Nile tilapia fillets, Marengoni \& Santos (2006) observed values ranging from 1.33 to $1.56 \mathrm{~g} / \mathrm{kg}$ of magnesium and 16.33 to $15.66 \mathrm{~g} / \mathrm{kg}$ of zinc; this suggests that this species contains considerable amounts of these minerals. Thus, the nutritional quality of the fresh pasta was improved through the addition of tilapia protein concentrate, because the inclusion of this ingredient increased the crude protein and lipid contents, decreased the caloric value, and improved the mineral profile of the pasta.

Regarding the sensory analysis results (Table 5), we observed that the color and aroma of fresh pasta containing different levels of tilapia protein concentrate did not present with a significant difference $(\mathrm{P}>0.05)$ among treatments. However, texture, overall impression, and the acceptance index displayed a cubic regression, with the inclusion of $20 \%$ of tilapia protein concentrate resulting in the best scores. The flavor scores decreased linearly $(\mathrm{P}<0.05)$ with the increase in tilapia protein concentrate.

According to Maluf et al. (2010), color and aroma were not affected by different treatments because the noodle samples were offered to the tasters with the addition of tomato sauce according. However, the other characteristics that were evaluated (texture, flavor, and overall impression) were influenced by the treatments, as observed in Table 5.

A cubic regression was observed for texture, overall impression, and for the acceptance index. These results indicate that the addition of $20 \%$ of tilapia protein concentrate in fresh pasta is ideal for improving the nutritional quality of noodles without affecting the sensory properties. Dutcosky (2007) recommended a minimum acceptance index of $70 \%$ for the product to be well accepted; the pasta with 0,10 , and $20 \%$ of tilapia protein concentrate showed a high level of acceptence (75.56, 71.00, and $77.6 \%$, respectively), with only the $30 \%$ level of protein concentrate presenting with an acceptance index lower than
$70 \%$. Bread with the inclusion of 3 and $5 \%$ of washed and dried Bluewing searobin pulp (Prionotus punctatus) presented with a good sensory acceptance index of 77.0 and $76.7 \%$, respectively (Centenaro et al., 2007).

In noodles with the inclusion of $5,10,15$, and $20 \%$ of Trahira ( $H$. malabaricus) protein concentrate, Costa et al. (1990) observed that the level of $20 \%$ supplementation was not considered acceptable by taster panels in terms of color and flavor. Kaminski et al., (2011) performed a sensory analysis of noodles with 25 and $75 \%$ of integral rye flour replacing wheat flour, and they observed a lower acceptance by tasters in terms of color, aroma, flavor, and texture characteristics in noodles with $75 \%$ of integral rye flour.

The results regarding the analysis of the noodle characteristics corroborate with the tasters' purchase intentions, all of which are presented in Table 5 . The inclusion of $30 \%$ of tilapia protein concentrate resulted in the lowest purchase intention (2.78). It was demonstrated that the increase in tilapia protein concentrate in noodles caused a linear decrease $\left(y=3.643-0.022 \times, R^{2}=0.62\right)$ in purchase intension, with average values ranging from 2.78 to 3.53 . Reis (2013) did not observe significant differences $(P>0.05)$ between formulations of dry pasta with tilapia pulp flour (2.5, $5.0,7.5$, and $10 \%)$ and the standard formulation $(0 \%)$ in terms of appearance, aroma, flavor, texture, overall impression, and purchase intention. In the purchase intention test, Reis (2013) observed values ranging from 3.40 to 3.62. Similar values for the inclusion of 0,10 , and $20 \%$ tilapia protein concentrate were found in the present study. Therefore, we realized that the inclusion of tilapia protein concentrate in noodles can significantly improve the nutritional value of this widely consumed product.

\section{Conclusion}

We concluded that the inclusion of up to $30 \%$ of tilapia protein concentrate in fresh pasta is able to linearly increase the crude protein and total lipids contents, decrease the caloric value of this product, and increase the calcium, phosphorus, magnesium, sodium, and zinc concentrations. However, based on the sensory results, we recommend a maximum inclusion level of $20 \%$ of tilapia protein concentrate in fresh pasta. The flour and the pasta contained a good microbiologic quality, meaning that they were well prepared with a minimal risk of contamination during the processing. 


\section{Acknowledgements}

The authors would like to thank the CNPq (Conselho Nacional de Desenvolvimento Científico e Tecnológico), CAPEs (Coordenação de Aperfeiçoamento de Pessoal de Nível Superior), Fundação Araucária and Fundect (Fundação de Apoio ao Desenvolvimento do Ensino, Ciência e Tecnologia do Estado de Mato Grosso do Sul).

\section{References}

American Public Health Association - APHA. (2001). Compendium of methods for the microbiological examination of foods. Washington: APHA.

Ariño, A., Beltrán, J. A., Herrera, A., \& Roncalés, P. (2013). Fish and seafood: nutritional value. In B Caballero. Encyclopedia of Human Nutrition (3th ed., pp. 254-261). Waltham: Elsevier. http://dx.doi. org/10.1016/B978-0-12-375083-9.00110-0.

Associations of Official Analytical Chemists - AOAC. (2005). Official Methods of Analyses of the Association of Analytical Chemists (18th ed.). Arlington: AOAC.

Belitz, H. D., Grosch, W., \& Schieberle, P. (2009). Food chemistry (4th ed.). Berlin: Springer.

Brasil. Ministério da Agricultura, Pecuária e Abastecimento. (2003, August 26). Oficializa os métodos analíticos oficiais para análises microbiológicas para controle de produtos de origem animal e água (Instrução Normativa n ${ }^{\circ} 62$ de 26 de agosto de 2003). Diário Oficial da República Federativa do Brasil.

Brasil. Ministério da Saúde. (2001, January 2). Aprova o Regulamento Técnico sobre padrões microbiológicos para alimentos (RDC $\mathrm{n}^{\circ}$ 12, de 2 de janeiro de 2001). Diário Oficial da República Federativa do Brasil.

Brasil. Ministério da Saúde. (2002, December 13). Aprova o Regulamento Técnico para fortificação das farinhas de trigo e das farinhas de milho com ferro e ácido fólico (RDC n³44, de 13 de dezembro de 2002). Diário Oficial da República Federativa do Brasil.

Centenaro, G. S., Feddern, V., Bonow, E. T., \& Salas-Mellado, M. (2007). Enriquecimento de pão com proteínas de pescado. Ciência e Tecnologia de Alimentos, 27(3), 663-668. http://dx.doi.org/10.1590/ S0101-20612007000300036.

Chen, C., Sun, B., Li, X., Li, P., Guan, W., Bi, W., \& Pan, Q. (2013). N-3 essential fatty acids in Nile tilapia, Oreochromis niloticus: Quantification of optimum requirement of dietary linolenic acid in juvenile fish. Aquaculture (Amsterdam, Netherlands), 416-417, 99-104. http:// dx.doi.org/10.1016/j.aquaculture.2013.09.003.

Costa, N. M. B., Coelho, D. T., \& Bicudo, M. H. (1990). Avaliação sensorial e nutricional de macarrão suplementado com concentrado protéico de pescado. Archivos Latinoamericanos de Nutricion, 40(2), 240-251. PMid:2133183.

Damásio, M. H., \& Silva, M. A. A. P. (1996). Curso de treinamento em análise sensorial (Apostila). Campinas: Fundação Tropical de Tecnologia "André Tosello."

Dutcosky, S. D. (2007). Análise sensorial de alimentos (2th ed., 239 p., Coleção Exatas). Curitiba: Champagnat.

Eijsink, L. M., Krom, M. D., \& Lange, G. J. (1997). The use of sequential extraction techniques for sedimentary phosphorus in eastern. Marine Geology, 139(1-4), 147-155. http://dx.doi.org/10.1016/ S0025-3227(96)00108-9.

Food and Agriculture Organization of the United Nations - FAO. World Health Organization - WHO. (2001). Human vitamin and mineral requirements: report 7th Joint FAO/WHO Expert Consultation Bangkok, Thailand (286 p.). Rome: FAO/WHO.

Fradique, M., Batista, A. P., Nunes, M. C., Gouveia, L., Bandarra, N. M., \& Raymundo, A. (2013). Isochrysis galbana and Diacronema vlkianum biomass incorporation in pasta products as PUFA's source. LWT - Food Science and Technology (Campinas.), 50, 312-319. http:// dx.doi.org/10.1016/j.lwt.2012.05.006.

Franco, M. L. R. S., Abreu, B. B., Saccomani, A. P. O., Vesco, A. P. D., Vieira, V. I., Mikcha, J. M. G., Gasparino, E., \& Delbem, A. C. B. (2013). Elaboración De cookies y galletas con inclusión de harina de pescado. Infopesca Internacional, 53, 30-33.

Fuchs, R. H. B., Ribeiro, R. P., Matsushita, M., Tanamati, A. A. C., Bona, E., \& Souza, A. H. P. (2013). Enhancement of the nutritional status of Nile tilapia (Oreochromis niloticus) croquettes by adding flaxseed flour. LWT - Food Science and Technology (Campinas.), 54, 440-446. http://dx.doi.org/10.1016/j.lwt.2013.07.004.

Giese, J. (1992). Pasta: New twists on an old product. Food Technology, 46, 118-126.

Godoy, L. C., Franco, M. L. R. S., Franco, N. P., Silva, A. F., Assis, M. F., Souza, N. E., Matsushita, M., \& Visentainer, J. V. (2010). Análise sensorial de caldos e canjas elaborados com farinha de carcaças de peixe defumadas: Aplicação na merenda escolar. Ciência e Tecnologia de Alimentos, 30, 86-89. http://dx.doi.org/10.1590/ S0101-20612010000500014.

Godoy, L. C., Franco, M. L. R.D. S., Souza, N. E., Stevanato, F. B., \& Visentainer, J. V. (2013). Development, preservation, and chemical and fatty acid profiles of Nile tilapia carcass meal for human feeding. Journal of Food Processing and Preservation, 37(2), 93-99. http:// dx.doi.org/10.1111/j.1745-4549.2011.00624.x.

Hosseini, H., Mahmoudzadeh, M., Rezaei, M., Mahmoudzadeh, L., Khaksar, R., Khosroshahi, N. K., \& Babakhani, A. (2014). Effect of different cooking methods on minerals, vitamins and nutritional quality indices of kutum roach (Rutilus frisii kutum). Food Chemistry, 148, 86-91. http://dx.doi.org/10.1016/j.foodchem.2013.10.012. PMid:24262530.

Instituto Brasileiro de Geografia e Estatística - IBGE. (2014). Produção da Pecuária Municipal. Rio de Janeiro: IBGE. 42, 1-39. Retrieved from http://biblioteca.ibge.gov.br/visualizacao/periodicos/84/ ppm_2014_v42_br.pdf

Justen, A. P., Franco, M. L. R. S., Monteiro, A. R. G., Mikcha, J. M. G., Gasparino, E., \& Delbem, A. B. (2011). Inclusión de harina de pescado en snacks. Infopesca Internacional, 47, 35-38.

Kaminski, T. A., Silva, L. P., Nascimento, A. Jr., \& Ferrão, T. S. (2011). Atributos nutricionais, tecnológicos e sensoriais de macarrões de centeio. Brazilian Journal of Food Technology, 14(02), 137-144. http:// dx.doi.org/10.4260/BJFT2011140200018.

Karppanen, H., \& Mervaala, E. (2006). Sodium intake and hypertension. Progress in Cardiovascular Diseases, 49(2), 59-75. http://dx.doi. org/10.1016/j.pcad.2006.07.001. PMid:17046432.

Maluf, M. L. F., Weirich, C. E., Dallagnol, J. M., Simões, M. R., Feiden, A., \& Boscolo, W. R. (2010). Elaboração de massa fresca de macarrão enriquecida com pescado defumado. Revista do Instituto Adolfo Lutz, 69, 84-90.

Marengoni, N. G., \& Santos, R. S. (2006). Rendimento e composição centesimal de filés de tilápia (Oreochromis niloticus) e piavuçu (Leporinus macrocephalus) cultivados em pesque-pagues. Archivos de Zootecnia, 55, 227-238.

Neves, R. A. M., Mira, N. V. M., \& Marquez, U. M. L. (2004). Caracterização de hidrolisados enzimáticos de pescado. Ciência e 
Tecnologia de Alimentos, 24(1), 101-108. http://dx.doi.org/10.1590/ S0101-20612004000100019.

Nicoletti, A. M., Silva, L. P., Hecktheuer, L. H., Toledo, G. S. P., \& Gutkoski, L. C. (2007). Uso de subprodutos agroindustriais no desenvolvimento de macarrão nutricionalmente melhorado. Alimentos e Nutrição, 18, 421-429.

Nilson, E. A. F., Jaime, P. C., \& Resende, D. O. (2012). Iniciativas desenvolvidas no Brasil para a redução do teor de sódio em alimentos processados. Revista Panamericana de Salud Pública, 32(4), 287-292. http://dx.doi.org/10.1590/S1020-49892012001000007. PMid:23299290.

Petenuci, M. E., Stevanato, F. B., Morais, D. R., Santos, L. P., Souza, N. E., \& Visentainer, J. V. (2010). Composição e estabilidade lipídica da farinha de espinhaço de tilápia. Ciência e Agrotecnologia, 34(5), 1279-1284. http://dx.doi.org/10.1590/S1413-70542010000500028.

Reis, T. A. (2013). Caracterização de macarrão massa seca enriquecido com farinha de polpa de pescado (Dissertação de mestrado). Universidade Federal de Lavras, Lavras.

Sartori, A. G. O., \& Amancio, R. D. (2012). Pescado: importância nutricional e consumo no Brasil. Segurança Alimentar e Nutricional, 19(2), 83-93.

Simões, M. R., Ribeiro, C. F. A., Ribeiro, S. C. A., Park, K. J., \& Murr, F. E. X. (2007). Composição físico-química, microbiológica e rendimento do filé de tilápia tailandesa (Oreochromis niloticus). Ciência e Tecnologia de Alimentos, 27(3), 608-613. http://dx.doi. org/10.1590/S0101-20612007000300028.
Souci, S. W., Fachman, H., \& Kraut, E. (2000). Foods composition and nutrition tables (6th ed., 1182 p.). Stuttgart: Medpharm GmbH Scientific Publishers.

Souza, M. L. R., Yoshida, G. M., Campelo, D. A. V., Moura, L. B., Xavier, T. O., \& Goes, E. S. R. (2016). Formulation of fish waste meal for human nutrition. Acta Scientiarum. Technology. In press.

Taskaya, L., Chen, Y., Beamer, S., Tou, J. C., \& Jaczynski, J. (2009). Compositional characteristics of materials recovered from whole gutted silver carp (Hypophthalmichthys molitrix) using isoelectric solubilization/precipitation. Journal of Agricultural and Food Chemistry, 57(10), 4259-4266. http://dx.doi.org/10.1021/jf803974q. PMid:19368395.

Vignesh, R., \& Srinivasan, M. (2012). Nutritional quality of processed head and bone flours of Tilapia (Oreochromis mossambicus, Peters 1852) from Parangipettai estuary, South East Coast of India. Asian Pacific Journal of Tropical Biomedicine, 2(1), S368-S372. http:// dx.doi.org/10.1016/S2221-1691(12)60189-0.

World Health Organization - WHO. Food and Agriculture Organization of the United Nations - FAO. UNU Expert Consultation. (2007). Proteins and amino acids in human nutrition (WHO Technical Report Series, No. 935, 265 p.). Geneva: WHO.

Zhou, H. Y., Cheung, R. Y. H., Chan, K. M., \& Wong, M. H. (1998). Metal concentrations in sediments and tilapia collected from inland waters of Hong Kong. Water Research, 32(11), 3331-3340. http:// dx.doi.org/10.1016/S0043-1354(98)00115-8. 